\title{
Evaluation of the effects of S-methylisothiourea hemisulfate, an inducible nitric oxide synthase inhibitor, on the healing of colonic anastomosis in rats $^{1}$
}

\author{
Avaliação dos efeitos da S-metilisotiouréia, um inibidor da enzima óxido nítrico sintase \\ induzível, na cicatrização de anastomoses colônicas em ratos
}

\begin{abstract}
Romulo Medeiros de Almeida', João Batista de Sousa ${ }^{I I}$, Paulo Roberto Faria Ribeiro ${ }^{\mathrm{III}}$, Silvana Marques e Silva ${ }^{\mathrm{IV}}$, Marco Aurélio Pereira Firminov, Paulo Gonçalves de Oliveira ${ }^{I I}$

${ }^{I}$ Master, Assistant Professor, Surgical Clinics, School of Medicine, UnB, Brasilia-DF, Brazil. Responsible for intellectual and scientific content of the study, designed the protocol, acquisition and interpretation of data, statistical analysis and manuscript writing

IIPhD, Associate Professor, Surgical Clinics, School of Medicine, UnB, Brasilia-DF, Brazil. Interpretation of data, critical revision and final approval.

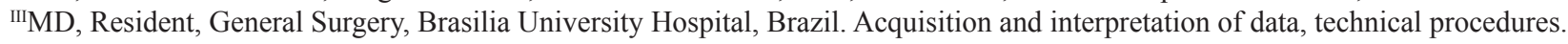

${ }^{\mathrm{IV}} \mathrm{PhD}$, Brasilia University Hospital, Colorectal Surgery, Brazil. Interpretation of data, statistical analysis and manuscript writing.

${ }^{\mathrm{v}}$ Graduate student, School of Medicine, UnB, Brasilia-DF, Brazil. Acquisition of data, technical procedures.
\end{abstract}

\section{ABSTRACT}

PURPOSE: To evaluate the effects of S-methylisothiourea hemisulfate (SMT) on the healing of colonic anastomosis in rats.

METHODS: Sixty rats Wistar were distributed into two groups of 30 animals: experimental (E) and control C). The animals of experimental group received intraperitoneal SMT at $50 \mathrm{mg} / \mathrm{kg} /$ dose every 12 hours for 72 hours. The control group received intraperitoneal saline at the same volume of SMT. The rats were subdivided into subgroups groups of 10 for euthanasia on the third, seventh, and $14^{\text {th }}$ postoperative days (POD). We evaluated clinical and weight evolution, breaking strength and histopathology; also, a blood sample was collected for serum dosage of nitrite/nitrate.

RESULTS: There was more vascular neoformation $(\mathrm{p}=0.006)$ and granulation $(\mathrm{p}=0.002)$ in the E3 group, and more mononuclear infiltrates in the $\mathrm{C} 3$ group ( $\mathrm{p}=0.041)$. There was also more edema in the $\mathrm{C} 14$ group $(\mathrm{p}=0.008)$. There was no statistically significant difference in breaking strength, nitrite/nitrate dosage, and the remaining histopathological parameters.

CONCLUSION: The use of S-methylisothiourea hemisulfate improved the healing of colonic anastomosis in rats on the third postoperative day by accelerating the proliferative stage of healing, but without interfering with the breaking strength of the anastomosis. Key words: Nitric Oxide. Nitric Oxide Synthase. Wound Healing. Anastomosis, Surgical. Colon. Rats.

\section{RESUMO}

OBJETIVO: Avaliar os efeitos do hemissulfato de S-metilisotiouréia (SMT) na cicatrização de anastomoses colônicas em ratos no terceiro, sétimo e $14^{\circ}$ dia de pós-operatório (DPO).

MÉTODOS: Sessenta ratos Wistar foram distribuídos em dois grupos: experimental (E) e controle (C), com 30 animais cada. No grupo experimental foi administrado SMT $50 \mathrm{mg} / \mathrm{kg} / \mathrm{dose}$, intraperitoneal a cada 12 horas por 72 horas. $\mathrm{O}$ grupo controle recebeu $\mathrm{NaCl}$ a $0,9 \%$. Os ratos foram subdivididos em grupos de 10 para eutanásia no terceiro, sétimo e $14^{\circ} \mathrm{DPO}$. Avaliou-se a evolução clínica e o peso dos animais, a resistência tênsil e histopatologia da anastomose, e a dosagem de nitrito/nitrato no soro.

RESULTADOS: Houve mais neoformação vascular $(p=0,006)$ e de granulação $(p=0,002)$ no grupo E3, e maior infiltração de mononucleares no grupo C3 ( $\mathrm{p}=0,041)$. Houve também mais edema no grupo C14 ( $\mathrm{p}=0,008)$. Não houve diferença estatisticamente significativa na resistência tênsil, a dosagem de nitrito / nitrato, e os restantes parâmetros histopatológicos.

CONCLUSÃO: A utilização do hemissulfato de S-metilisotiouréia acelerou a cicatrização das anastomoses colônicas, a melhoria ocorreu no terceiro DPO: verificou-se que a fase proliferativa da cicatrização foi acelerada. Não houve interferência na resistência tênsil das anastomoses.

Descritores: Óxido Nítrico. Oxido Nítrico Sintase. Cicatrização. Anastomose Cirúrgica. Colo. Ratos. 


\section{Introduction}

The metabolism of nitric oxide (NO) has been widely investigated in wound healing, especially in intestinal anastomosis. NO is synthesized by macrophages and is an important cell mediator of tissue repair. The release of NO is found to increase during trauma, surgical stress, and sepsis. Macrophage oxidation of L-arginine to NO is catalyzed by nitric oxide synthases (NOS). This process also generates citruline and the intermediate hydroxyL-arginine. There are three enzyme isoforms: two are constitutive (neuronal and endothelial) and one is inducible (inducible nitric oxide synthase, iNOS) ${ }^{1}$.

During healing of wounds and burns there is an increase in iNOS activity ${ }^{2}$. The resulting increase in NO formation may have a negative influence on fibroblast collagen synthesis; it may also deteriorate cases of inflammation and sepsis. The increase has also been implicated in the pathophysiology of a variety of diseases, including circulatory shock. Studies show that nitrite and nitrate are the stable metabolites for the consumption of L-arginine and production of $\mathrm{NO}$, and their plasma or urine dosage represent this production ${ }^{3,4}$.

Several drugs may reduce or inhibit the effects of NOS. One such drug is S-methylisothiourea hemisulfate (SMT). Several studies have shown the specificity of SMT for iNOS. SMT in vitro is 10 to 30 times more potent than any other iNOS inhibitor ${ }^{4}$.

Shaffer et $a l . .^{5}$ showed that wound fibroblasts are phenotypically altered during the healing process to synthesize NO. The authors also showed that SMT in vitro not only reduces NO synthesis, but also does not affect the proliferation of fibroblasts and increases collagen contractility.

The aim of the present study was to evaluate the effects of S-methylisothiourea hemisulfate on colonic anastomosis healing in rats.

\section{Methods}

The present study was approved by the Ethics Committee for Animal Use of the Biological Sciences Insitute at Brasilia University. All experiments and procedures were performed in accordance with the Brazilian guidelines involving animals in research.

The study used 60 male, healthy Wistar rats (rattus norvergicus); rat body weight ranged between $248 \mathrm{~g}$ and $364 \mathrm{~g}$; age ranged between 90 to 120 days. Rats were randomized into two groups, experimental (E) and control (C), with 30 rats in each group. The rats were subdivided into groups of 10 rats for euthanasia on the third (subgroups E3 and C3), seventh (subgroups E7 and C7), and $14^{\text {th }}$ (E14 and C14) POD.

Animals in the experimental group were given intraperitoneal SMT (S-Methylisothiourea hemisulfate salt, Sigma-Aldrich Co, São Paulo, SP, Brazil) at $50 \mathrm{mg} / \mathrm{kg} / \mathrm{dose}$ every 12 hours. The administration started at the end of surgery and was maintained for 72 hours. Animals in the control group were administered salina at $0.9 \%$ following the same procedures established for the experimental group ${ }^{6}$.

General anesthesia was induced using $5 \mathrm{mg} / \mathrm{kg}$ of weight xylazine hydrochloride (Rompum $^{\mathrm{TM}}$ ) and $25 \mathrm{mg} / \mathrm{kg}$ of weight ketamine hydrochloride $\left(K_{\text {Ketamin }}^{\mathrm{TM}}\right.$ ) via intramuscular injection. Next, we performed a midline incision and identification of the descending colon, resection of $1 \mathrm{~cm}$ of colon $3 \mathrm{~cm}$ above the peritoneal reflection, and termino-terminal anastomosis (6-0 polypropylene suture) $)^{7}$

Reoperation was carried out on the previously set date for each group. Nitrite/nitrate (NOx) concentrations were measured using the Greiss reaction on serum obtained after centrifuging $5 \mathrm{ml}$ of arterial blood (drawn by cardiac puncture). We carried out resection of a central part of the intestine submitted to anastomosis; the segment was then longitudinally divided. One segment was used for analysis of the tensile strength. Analysis was performed using a digital test apparatus named Versa Test (Mecmesin ${ }^{\text {TM }}$ Versa Test, United Kingdom) coupled to a digital dynamometer AGF (Mecmesin $^{\mathrm{TM}}$ Versa Test, United Kingdom). Breaking strength was expressed in Newtons (N). Histopathological evaluation was carried out on the second segment by an experienced pathologist blind to animal groups. The evaluation was carried out with hematoxylin and eosin staining. The following indicators were evaluated: congestion, edema, focal hemorrhage, ulceration, necrosis, mononuclear infiltrates, polymorphonuclear infiltrates, vascular neoformation, granulation, and fibrosis. Each indicator was classified as absent $(-)$, mild $(+)$, moderate $(++)$, strong $(+++)$, or severe $(++++)$, as described by Sousa et $a l .^{8}$. All animals killed in the PO period were submitted to necropsy.

Statistical analysis was carried out using SPSS (version 12.0) and Sigma Stat (version 32). To compare initial and final weights, and NOx serum dosage was used one-way ANOVA and t-test. To evaluate the histopathological criteria was used Fisher's exact test. Statistical analyses were considered significant for $\mathrm{p}<0.05$.

\section{Results}

Six animals died during the experiment: one from 
subgroup E3, two from subgroup E7, two from subgroup E14, and one from subgroup $\mathrm{C} 3$. All deaths occurred in the immediate PO period. Necropsy did not show signs of intraabdominal or intrathoracic bleeding, abscess, anastomosis dehiscence, or peritonitis.

The initial weight of animals was similar in both groups $(\mathrm{p}=0.454)$; the average weight was $313.21 \mathrm{~g}(95.0 \% \mathrm{CI}=304.28$ $322.14)$ for the experimental group, and $311.54 \mathrm{~g} \quad(95.0 \%$ $\mathrm{CI}=303.55-319.54)$ for the control group. There was an initial weight loss in both groups, which was also not different between the groups. By the end of the study, animals regressed to their initial weight. The comparison of animal weight in each subgroup, carried out at the time of euthanasia on the third, seventh, and $14^{\text {th }}$ POD, did not show a statistically significant difference (Figure 1).

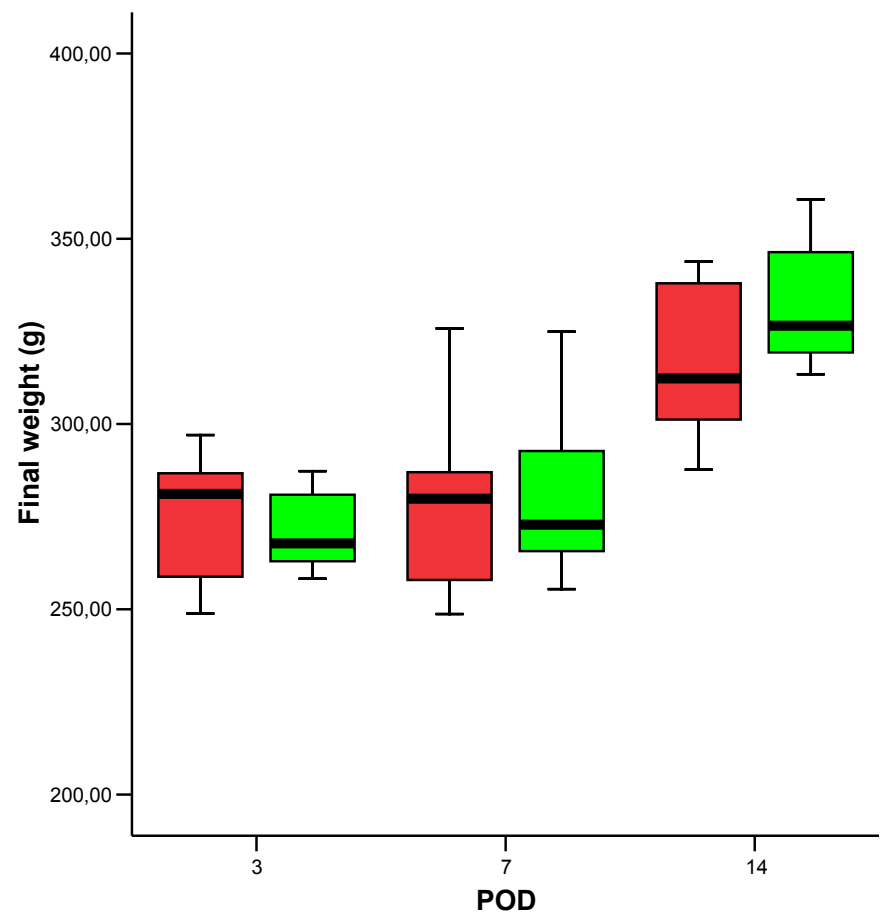

FIGURE 1 - Median and interval for animal weight in both groups and according to postoperative day of euthanasia (weight in grams).

Legend: third (3), seventh (7), $14^{\text {th }}$ (14) POD, SMT = S-methylisothiourea hemisulfate

Intracavitary adhesions were shown in $88.9 \%$ of animals of subgroup E3, and in $100.0 \%$ of animals in the other subgroups. Adhesions showed lower resistance to breaking on the third postop day and became more resistant on the seventh and $14^{\text {th }}$ days. Incidence of anastomosis dehiscence was one on control group and four on the SMT group but there was no difference between the subgroups $(\mathrm{p}=0.05)$. Anastomosis dehiscence was blocked by the omentum and adjacent organs. There were no cases of diffuse peritonitis, abscess, or anastomosis leakage.
Breaking strength increased with time in all subgroups with no statistically significant differences between them (Figure 2).

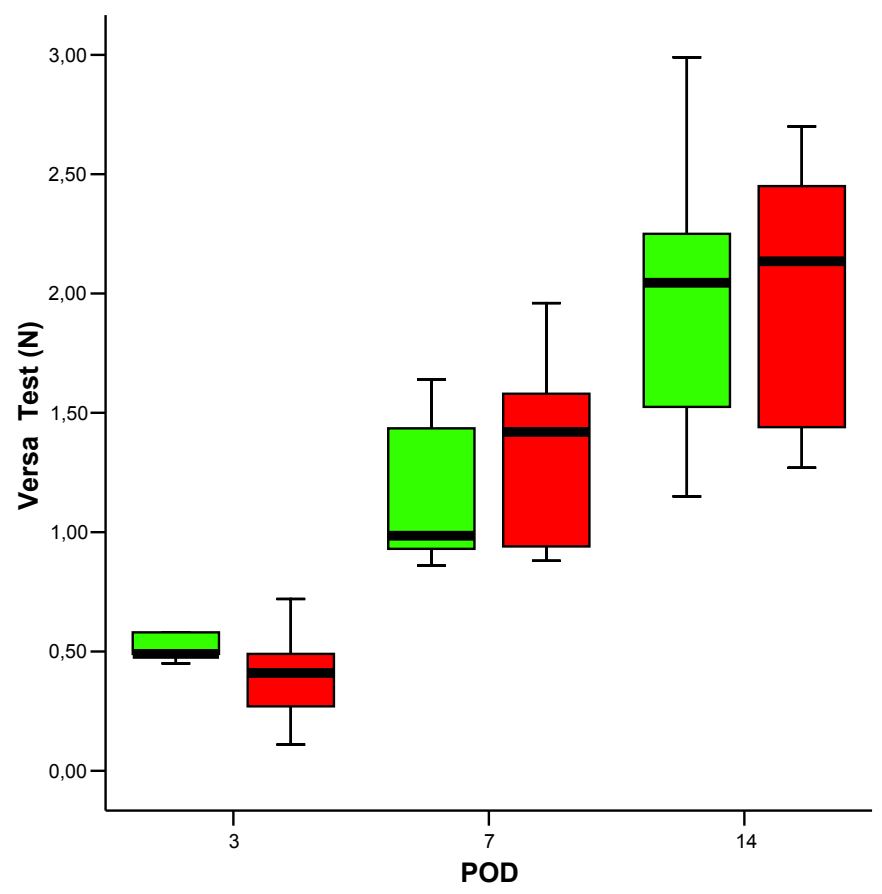

FIGURE 2 - Median and intervals for breaking strength of anastomoses in the different groups and subgroups (values in Newtons). Legend: third (3), seventh (7); $14^{\text {th }}$ (14) POD; SMT = S-methylisothiourea hemisulfate

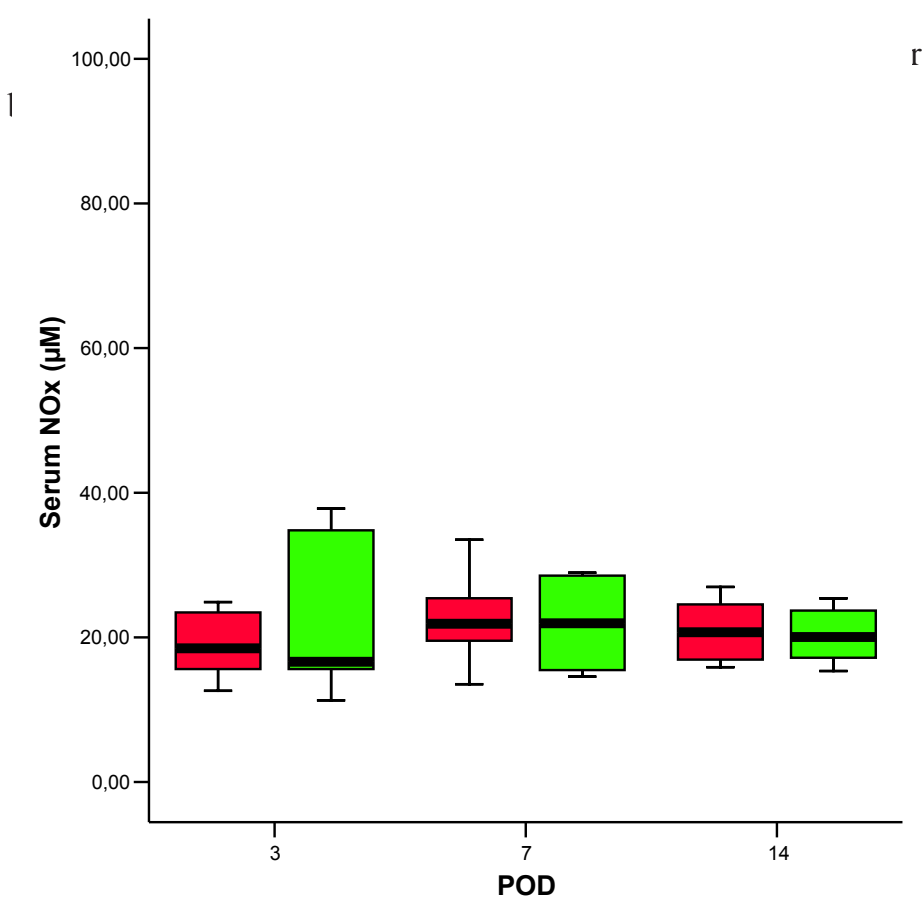

FIGURE 3 - Median and intervals for nitrite dosage in serum collected at euthanasia (values in $\mu \mathrm{M}$ ).

Legend: third (3), seventh (7); $14^{\text {th }}$ (14) POD; SMT = S-methylisothiourea hemisulfate 
Group E3 showed significantly more vascular neoformation $(\mathrm{p}=0.002)$ and more granulation $(\mathrm{p}=0.0001)$. Subgroup E14 had a stastically significant greater presence of edema in comparison to $\mathrm{C} 14(\mathrm{p}=0.002)$; this difference was not observed in the third and seventh POD. There were no differences between the groups in presence of congestion, focal hemorrhage, ulceration, necrosis, mononuclear infiltrates, or fibrosis.

\section{Discussion}

SMT is one of the most selective drugs among iNOS inhibitors. Other studies have been carried out on the effect of SMT on colon anastomoses healing with intraperitoneal injections that ranged from $3.0 \mathrm{mg} / \mathrm{kg}$ /day to $200 \mathrm{mg} / \mathrm{kg} /$ day (every 12 hours or by continuous infusion $)^{4,6,9}$. In the present study, SMT was administered at $72 \mathrm{~h}$. The rationale behind this choice is that iNOS is more active during the first days after surgical trauma. iNOS peaks during the first 24 hours and remains active for up to 10 days ${ }^{10}$. Other authors have corroborated the finding that the most active period of NOS is during the early stages of wound healing ${ }^{11}$.

The mortality rate in the study was $10 \%$. Deaths were most likely caused by anesthetic complications: there were no signs of bleeding, anastomosis dehiscence, or peritonitis. Previous studies on healing of intestinal anastomoses in rats have reported mortality rates that ranged from zero to $11.4 \% 0^{7,12,13}$.

The weight loss was followed by weight recovery up until the $14^{\text {th }}$ POD. The losses may have been associated with surgical stress $^{14}$. Weight loss has been described in previous studies on wound healing ${ }^{15,16}$. Others reported weight recovery as early as the seventh $\mathrm{POD}^{17}$.

The increase in breaking strength found with the passing of the PO period in both groups corroborates other studies in the literature ${ }^{18}$. The lack of a statistically significant difference on the third POD might be because the operated area is kept together by the suture during this period ${ }^{19}$.

The histopathological evaluation by an experienced examiner blind to experimental groups is an important criterion for the evaluation of the evolution of the healing of colon anastomoses ${ }^{7,8}$. Among the indicators evaluated, there was a statistically significant higher presence of vascular neoformation and granulation in group E3; of necrosis in subgroup C3; and of edema in subgroup E14. These findings indicate that iNOS inhibition by SMT favored an improvement in the process of healing.

The study did not show any difference between the subgroups for plasma dosage of nitrite/nitrate on the third, seventh, and $14^{\text {th }}$ POD. This result was not expected; our expectation was that there would be a higher dosage of nitrite/nitrate on the third POD. This dosage would decrease with time and, in the experimental group (i.e. administered SMT), the dosage of NO would be smaller than in the control group.

\section{Conclusion}

The use of S-methylisothiourea hemisulfate improved the healing of colonic anastomosis in rats on the third postoperative day by accelerating the proliferative stage of healing, but without interfering with the breaking strength of the anastomosis.

\section{References}

1. Moncada S, Palmer RM, Higgs EA. Nitric oxide: physiology, pathophysiology, and pharmacology. Pharmacol Rev. 1991;43(2):109-42.

2. Witte MB, Barbul A. Role of nitric oxide in wound repair. Am J Surg. 2002;183(4):406-12.

3. Marletta MA, Yoon PS, Iyengar R, Leaf CD, Wishnok JS. Macrophage oxidation of L-arginine to nitrite and nitrate: nitric oxide is an intermediate. Biochemistry. 1988;27(24):8706-11.

4. Szabo C, Southan GJ, Thiemermann C. Beneficial effects and improved survival in rodent models of septic shock with S-methylisothiourea sulfate, a potent and selective inhibitor of inducible nitric oxide synthase. Proc Natl Acad Sci U S A. 1994;91(26):12472-6

5. Schaffer MR, Efron PA, Thornton FJ, Klingel K, Gross SS, Barbul A. Nitric oxide, an autocrine regulator of wound fibroblast synthetic function. J Immunol. 1997;158(5):2375-81.

6. Aranow JS, Zhuang J, Wang H, Larkin V, Smith M, Fink MP. A selective inhibitor of inducible in nitric oxide synthase prolongs survival in a rat model of bacterial peritonitis: comparison with two nonselective strategies. Shock. 1996;5(2):116-21.

7. de Oliveira PG, Soares EG, Aprilli F. Influence of misoprostol, a synthetic prostaglandin E1 analog, on the healing of colonic anastomoses in rats. Dis Colon Rectum. 1994;37(7):660-3.

8. de Sousa JB, Soares EG, Aprilli F. Effects of diclofenac sodium on intestinal anastomotic healing. Experimental study on the small intestine of rabbits. Dis Colon Rectum. 1991;34(7):613-7.

9. Xu X, Cubeddu LX, Malave A. Expression of inducible nitric oxide synthase in primary culture of rat bladder smooth muscle cells by plasma from cyclophosphamide-treated rats. Eur J Pharmacol. 2001;23;416(1-2):1-9.

10. Lee RH, Efron D, Tantry U, Barbul A. Nitric oxide in the healing wound: a time-course study. J Surg Res. 2001;101(1):104-8.

11. Albina JE, Mills CD, Henry WL, Jr., Caldwell MD. Temporal expression of different pathways of 1-arginine metabolism in healing wounds. J Immunol. 1990;144(10):3877-80.

12. Marques e Silva S, de Oliveira MV, Brandao AM, Carneiro FP, Ferreira VM, Parra RS, Feres O, Sousa JB. Study on adhesion formation and the healing of colon anastomosis in rats with induced peritoneal sepsis. Acta Cir Bras. 2011;26 Suppl 2:100-5.

13. Oliveira MV, Brandao AM, Morais PH, Silva NG, Silva SM, Carneiro FP, Sousa JB. Effects of bromopride on abdominal wall healing with induced peritoneal sepsis after segmental colectomy and colonic anastomosis in rats. Acta Cir Bras. 2011;26(6):433-7. 
14. Oliveira PG, Sousa JB, Reys LG, Magalhaes AV, Rabelo Fde S, Muniz KC. Effects of enoxaparin on the healing of abdominal wall in rats: study on breaking strength and histopathology. Acta Cir Bras. 2006;21(4):247-51

15. Brandao AM, da Silva NG, de Oliveira MV, de Morais PH, Marques e Silva S, de Sousa JB, Carneiro FP. Effects of abdominal sepsis in the healing of abdominal wall: experimental study in rats. Acta Cir Bras. 2011;26 Suppl 2:38-44.

16. da Silva NG, Brandao AM, de Oliveira MV, de Morais PH, Marques e Silva S, Carneiro FP, Sousa JB. Influence of metoclopramide on abdominal wall healing in rats subjected to colonic anastomosis in the presence of peritoneal sepsis induced. Acta Cir Bras. 2011;26 Suppl 2:92-9.

17. Mastboom WJ, Hendriks T, de Man BM, de Boer HH. Influence of methylprednisolone on the healing of intestinal anastomoses in rats. Br J Surg. 1991;78(1):54-6.

18. Silva SM, Ferreira VM, Feres O, Oliveira PG, Sousa JB. Does metoclopramide impair anastomotic healing of the left colon of rats? Acta Cir Bras. 2011;26(4):297-302.

19. Thornton FJ, Barbul A. Healing in the gastrointestinal tract. Surg Clin North Am. 1997;77(3):549-73

\section{Correspondence:}

Romulo Medeiros de Almeida

SHC/SW Lotes 3/5 - Sala 154 - Térreo

Centro Clínico Sudoeste

Setor Sudoeste

70640-000 Brasília - DF Brasil

Tel./Fax: (55 61)3361-2100

romuloprocto@hotmail.com

Received: July 27, 2012

Review: September 28, 2012

Accepted: October 30, 2012

Conflict of interest: none

Financial source: none

${ }^{1}$ Research performed at Experimental Laboratory of Surgery, School of Medicine, Brasilia University (UnB), Brazil. 